\title{
Transport accident mortality in Chile: trends from 2000 to 2012
}

\author{
A mortalidade por acidentes de transporte em Chile: \\ tendências de 2000 a 2012
}

\author{
Tamara Otzen ${ }^{1}$ \\ Antonio Sanhueza ${ }^{2}$ \\ Carlos Manterola $^{3}$ \\ Monica Hetz ${ }^{4}$ \\ Tamara Melnik ${ }^{5}$
}

${ }^{1}$ Facultad de Ciencias de la Salud, Universidad de Tarapacá. Calle 18 de Septiembre 2222. 1010069 Arica Tarapaca Chile. tamara.otzen@ufrontera.ch

${ }^{2}$ Pan American Health Organization. Washington USA.

${ }^{3}$ Universidad de La Frontera. Temuco Chile.

${ }^{4}$ Universidad Católica de Temuco. Temuco Chile.

${ }^{5}$ Programa de PósGraduação em Saúde Baseada em Evidências, Universidade Federal de São Paulo. São Paulo SP Brasil.

\begin{abstract}
The aim of this study is to describe the trends of transport accident mortality in Chile from 2000 to 2012 by year, geographic distribution, gender, age group, and type of accident. Population-based study. Data for transport accident mortality in Chile between 2000 and 2012 were used. The crude and adjusted per region transport accident mortality rates were calculated per 100,000 inhabitants. The annual percentage change $(A P C)$ of the rates and relative risks $(R R)$ were calculated. The average transport accident mortality rate (TAMR) in Chile (2000-2012) was 12.2. The rates were greater in men (19.7) than in women (4.8), with a $R R$ of 4.1 . The rates were higher in the country's southern zone (15.9), increasing in recent years in the southern zone, with a significant positive APC in the northern and central zones. The Maule region had the highest rate (21.1), although Coquimbo was the region with the most significant APC (2.2\%). The highest rate (20.3) was verified in the 25-40 age group. The highest rate (14.3) was recorded in 2008. The most frequent type of accident was pedestrian. In general the APC trends of the rates are increasing significantly. This, added to rapid annual automotive growth, will only exacerbate mortality due to transport accidents.
\end{abstract}

Key words Transport accidents, Mortality, Chile, Latin America
Resumo O objetivo deste estudo é descrever as tendências da mortalidade por acidente em transporte no Chile, entre 2000-2012, por ano, distribuição geográfica, gênero, idade e tipo de acidente. Estudo populacional. Foram usados dados de mortalidade por acidentes de transporte entre 2000-2012. Taxas brutas e ajustadas de mortalidade por acidentes no transporte por região foram calculadas por 100.000 habitantes. A variação percentual anual (APC) da taxa e os riscos relativos (RR) foram calculados. A taxa média de mortalidade por acidentes no transporte (TAMR) no Chile (2000-2012) foi de 12,2. As taxas dos homens (19.7) foram maiores que as das mulheres (4.8), com RR de 4.1. As taxas foram mais elevadas no sul do país (15.9), apresentando crescimento nos últimos anos, com uma APC significativa e positiva nas áreas norte e central. A região de Maule teve a maior taxa (21.1), embora a de Coquimbo tenha apresentado APC (2.2\%) significativa. A taxa mais elevada (20.3) foi verificada no grupo de 25-40 anos. Em 2008 foi registrada a taxa mais elevada (14.3). O tipo mais frequente de acidente é o que envolve pedestres. Em geral, a APC tende a apresentar crescimento significativo. Isto, somado a um rápido crescimento automotivo anual, só irá agravar a mortalidade por acidentes de transporte.

Palavras-chave Acidentes de transporte, Mortalidade, Chile, América Latina 


\section{Introduction}

According to calculations by the World Health Organization (WHO), 56 million people died worldwide in 2012, of whom 1.24 million were due to transport accidents, which represents almost 3,500 deaths/day (600 more deaths/day than in 2000). These data put transport accidents as the ninth cause of death in the world and seventh in middle-high income countries ${ }^{1}$. Current trends indicate that transport accidents will become the fifth cause of death by $2030^{2}$.

The International Statistical Classification the Diseases and Related Health Problems, Tenth Edition (ICD-10) is one of the most frequently used international standards to prepare statistics of morbidity and mortality in the world ${ }^{3}$. Transport accidents are defined as any accident involving a means designed essentially to take to people or goods from one place to another, or used primarily for that purpose at the time of the accident. They are included in chapter XX, codes V01-V99 (external causes of morbidity and mortality), and are divided according to: the type of injury (pedestrian, pedal cyclist, motorcyclist, occupant of vehicle), the type of vehicle involved (from bicycle to air transport), type of accident (with active or passive participation), and unspecified others ${ }^{3}$.

In 2012, transport accidents were the main cause of death in the 5-14 age group in the Americas, and the second cause in the 15 to 44 age group, which in crude terms means a total of 142,252 deaths, and the number of injured people is estimated to be more than 5 million. In the Southern Cone, $28.6 \%$ of deaths are a result of transport accidents ${ }^{2,4}$.

In a study that used figures from 2006-2007 for transport accidents, Chile, with a mean rate of 13.7 per 100,000 inhabitants, was below the mean rate for the Americas $(15.8)^{2}$. It must also be noted that there were 73,276 transport accidents in Chile in 2013, of which 1,623 were fatalities $^{5}$. These numbers denote a mortality rate of 9.2 per 100,000 inhabitants ${ }^{6}$. In addition, in 2012 there were 11,485 more transport accidents than in the 2010 with an increase of 100 in the number of fatalities?.

In Chile, the main causes of fatal transport accidents between 2000 and 2012 were: pedestrian recklessness, driver recklessness, presence of alcohol, and loss of control by the driver (total $76.7 \%)^{5}$. In 2012 the type of transport accidents with the greatest number of fatalities was pedestrian collision (42.7\%). The age group with the highest mortality by transport accidents according to 2012 figures was 19 - 63 (84.7\%). In addition more men (83\%) died than women 5 .

A large part of the research conducted in Chile has only been descriptive, without delving more deeply into the relationship of these rates to other variables. Far from this trend, in 2014 a study in Chile was carried out that sought to determine how the reform of the 2005 traffic law, police behavior and investment in highway infrastructure affected fatal traffic accidents and those causing severe casualties between 2000 and 2012. It found that they brought about a reduction in deaths and accidents, from $7 \%$ to $60 \%{ }^{8}$. Worldwide, a meta-analysis performed with studies from 1975 to 2007 found that road safety campaigns reduced accidents by $9 \%$. Another study was published in 2015 to determine the effects of the increase in police traffic enforcement recorded after the introduction of Chile's 2005 traffic law reform on reducing traffic fatalities and injuries; it reported that the introduction of the reform and legal penalties actually did have the desired effect for the 2007-2012 period ${ }^{10}$.

In addition to the suffering that this issue represents for those injured and their relatives, it also produces a considerable demand for pre-hospital and hospital trauma care, with the resulting overload in health care services and the high cost involved for society as a whole ${ }^{2}$.

In this light, the aim of this study was to describe the transport accidents mortality trends in Chile between 2000 and 2012 by year, gender, age group, geographic distribution, and type of accident.

\section{Materials and methods}

Design: Population-based study.

Subjects: The databases used were provided by the National Office of the Chilean Forensic Medical Service (SML) and Pan-American Health Organization (PAHO). Specifically, the SML gave us the number of deaths from 2000 to 2012 by sex and region, and the PAHO the number of deaths from 2000 to 2011 by age group and type of accident.

Deaths classified with codes V01-V99 of basic cause of death according to the ICD-10 were selected $^{3}$.

Study variables: Year, geographic distribution, gender, age group, and type of accident.

The variable geographic distribution grouped the regions of Chile into three zones: 
northern (regions of Tarapacá, Antofagasta, Arica and Parinacota, Atacama, and Coquimbo), central (regions of Valparaíso, Libertador Bernardo O'Higgins, Maule and Metropolitan), and southern (regions of Bío Bío, La Araucanía, Los Lagos, Los Ríos, Aisén, Magallanes and Chilean Antarctica). This grouping takes the geographical distribution of Chile into account, in addition to what has been done in previous studies ${ }^{11,12}$. The variable age was used categorically in 5 groups (under $16 ; 17$ to $24 ; 25$ to $40 ; 41$ to 59 ; and over $60)$. The variable type of accident was used categorically, classifying it according to the ICD-10, codes V01-V99. The classification was as follows: 1) V01-V09 "Pedestrian injured in transport accident"; 2) V10-V19 "Pedal cyclist injured in transport accident"; 3) V20-V39 "Motorcycle rider injured in transport accident" and "Occupant of three-wheeled motor vehicle injured in transport accident"; V40-V49 "Car occupant injured in transport accident”; V50-V59 “Occupant of pick-up truck or van injured in transport accident"; V60-V69 "Occupant of heavy transport vehicle injured in transport accident”; V70-V79 "Bus occupant injured in transport accident"; V80-V88 "Other land transport accidents specified"; V89 "Other land transport accidents unspecified"; V90-V99 "Water transport accidents", "Air and space transport accidents" and "Other and unspecified transport accidents"

Data analysis: Exploratory analyses were performed using the raw data. Descriptive statistics were applied, calculating percentages, measures of central tendency, and variability. The crude transport accident mortality rates (TAMR) per region were calculated per 100,000 inhabitants and this information was used to create the tables and graphs. The weighted calculation of rates was applied, so the percentage of total representation of inhabitants in the country according to the number of inhabitants in each region was included $^{1}$; these data were obtained from the Chilean National Statistics Institute (INE) $)^{13,14}$.

Then, an analysis was made of the annual percentage change (APC) of the rates, using a linear regression model with the respective 95\% confidence intervals (CI) and p value ${ }^{15}$. Next, the logarithm of the rates standardized per year and region was fitted by applying a linear regression model, which enabled estimation of the average annual change in the percentage rate, the $\mathrm{CI}$ and $\mathrm{p}$ values. Finally, relative risks (RR) were determined by geographic distribution, gender, age group, and type of accident, calculating their respective APC and 95\% CI. The regression model was developed to identify the relation between the year and the rates in the different groups, thereby identifying whether the annual variation has significant variations and predicting the increase in the rates in the coming years ${ }^{11,12,15}$.

To complement these analyses, the gross mortality rates for transport accidents per 100,000 vehicles was calculated, also calculating the APC ${ }^{15}$.

The analyses were performed using the STATA v. 9.0 statistics software.

Ethics: This study did not require the application of ethical safeguards, as official Chilean government statistics were used for the analyses.

\section{Results}

In Chile between 2000 and 2012 there were 25,889 deaths by transport accidents, of which $20,748(80.1 \%)$ were men. The TAMR in this period was 12.2 (Table 1 ). The years with the highest TAMR were 2008, 2006 and 2009 (14.3; 13.0 and 12.6, respectively). The years with the lowest TAMR were 2002 and 2001 (10.7 and 10.9, respectively) (Table 2 ).

By region, the highest rates 2000-2012 were observed in Libertador Bernardo O'Higgins, Maule and Arica and Parinacota (21.3; 19.1 and 17.1, respectively). In 2008, this difference changed, there being no trend in the regions with higher or low rates (Table 1).

Analyzing by geographic zone in the study, it was observed that the zone with the highest TAMR was the north (13.4) and the one with the lowest TAMR was the center (11.4). This trend has appeared in recent years, since from 2000 to 2003 and 2005 it was the central zone that led the rates, and in 2004, 2006 and 2007 it was the southern zone with the highest TAMR (Table 1) (Figure 1).

Contrasting TAMR by gender verified that the TAMR were always higher in men than women. Both men and women presented their highest TAMR in 2008 (22.7 and 6.0, respectively). In 2001, the men presented the lowest TAMR (17.3); a situation that occurred in women in 2003 (3.8) (Table 2) (Figure 2).

In relation to the TAMR in the different age groups, from 2000 to 2012 the highest mortality rate was verified in the 25 to 40 age group (20.3); the lowest rate was in the group under $16(6.0)$. These differences remained constant every year with the exception of 2004, when the group over 61 years of age had the lowest rate (Table 1 ).

In relation to the TAMR, it was verified that between 2000 and 2011 there were 12,080 deaths 
Table 1. Transport accident mortality rate per 100,000 population with their respective 95\% CI.

\begin{tabular}{|c|c|c|c|c|c|}
\hline \multirow[b]{2}{*}{ General rate } & \multirow{2}{*}{$\begin{array}{r}\text { Rate } \\
12.2\end{array}$} & \multirow{2}{*}{$\begin{array}{r}\text { APC } \\
0.45\end{array}$} & \multicolumn{2}{|c|}{ CI } & \multirow{2}{*}{$\frac{\mathbf{p}}{0.07}$} \\
\hline & & & 0.02 & 0.89 & \\
\hline Men & 19.7 & 0.36 & -0.07 & 0.80 & 0.13 \\
\hline Women & 04.8 & 0.82 & 0.08 & 1.56 & 0.05 \\
\hline Northern Zone & 13.4 & 2.36 & 1.45 & 3.28 & 0.00 \\
\hline Central Zone & 11.4 & -0.16 & -0.76 & 0.44 & 0.61 \\
\hline Southern Zone & 12.7 & 1.05 & 0.35 & 1.76 & 0.01 \\
\hline $\begin{array}{l}\text { Arica and } \\
\text { Parinacota }\end{array}$ & 17.1 & 1.37 & 0.21 & 2.54 & 0.04 \\
\hline Tarapacá & 15.3 & 1.36 & 0.00 & 2.73 & 0.08 \\
\hline Antofagasta & 12.4 & 3.41 & 0.35 & 4.82 & 0.00 \\
\hline Atacama & 12.5 & 1.13 & -0.37 & 2.64 & 0.17 \\
\hline Coquimbo & 12.8 & 3.08 & 1.67 & 4.50 & 0.00 \\
\hline Valparaíso & 10.7 & -0.52 & -1.77 & 0.75 & 0.44 \\
\hline Metropolitan & 9.5 & -0.56 & -0.94 & -0.19 & 0.01 \\
\hline L. B. O'Higgins & 21.3 & -0.62 & -1.42 & 0.19 & 0.16 \\
\hline Maule & 19.1 & 1.52 & 0.13 & 2.94 & 0.06 \\
\hline Bío Bío & 12.3 & 1.32 & 0.42 & 2.22 & 0.02 \\
\hline La Araucanía & 14.6 & 0.81 & -0.04 & 1.67 & 0.09 \\
\hline Los Ríos & 12.2 & 0.96 & -0.12 & 2.06 & 0.11 \\
\hline Los Lagos & 12.5 & 3.08 & 1.01 & 5.19 & 0.01 \\
\hline Aisén & 10.3 & 1.38 & -2.46 & 5.38 & 0.50 \\
\hline $\begin{array}{l}\text { Magallanes and } \\
\text { Ch. Ant. }\end{array}$ & 10.8 & 1.22 & -0.96 & 3.44 & 0.30 \\
\hline 0 to 16 & 6.0 & -0.01 & -0.78 & 0.77 & 0.98 \\
\hline 17 to 24 & 14.2 & -0.49 & -1.02 & 0.04 & 0.10 \\
\hline 25 to 40 & 20.3 & -0.37 & -0.86 & 0.13 & 0.17 \\
\hline 41 to 59 & 17.1 & -0.35 & -0.76 & 0.07 & 0.13 \\
\hline 61 or older & 7.7 & 0.47 & -0.24 & 1.19 & 0.23 \\
\hline
\end{tabular}

Table 2. Transport accident mortality rate per 100,000 population, by year and gender.

\begin{tabular}{ccccc}
\hline Year & $\mathbf{n}$ & Rate & Men & Women \\
\hline 2000 & 1767 & 11.48 & 18.52 & 4.58 \\
2001 & 1700 & 10.92 & 17.35 & 4.62 \\
2002 & 1676 & 10.70 & 17.61 & 3.92 \\
2003 & 1791 & 11.31 & 18.99 & 3.78 \\
2004 & 1998 & 12.49 & 20.86 & 4.27 \\
2005 & 2005 & 12.40 & 20.25 & 4.71 \\
2006 & 2130 & 13.04 & 20.47 & 5.76 \\
2007 & 2041 & 12.37 & 20.53 & 4.36 \\
2008 & 2381 & 14.27 & 22.71 & 5.99 \\
2009 & 2123 & 12.58 & 20.40 & 4.92 \\
2010 & 2103 & 12.32 & 19.76 & 5.04 \\
2011 & 2131 & 12.35 & 19.69 & 5.15 \\
2012 & 2043 & 11.71 & 18.61 & 4.95 \\
\hline
\end{tabular}

by "pedestrian injured in transport accidents" (43.1\%), and 8,756 deaths by "other unspeci- fied land transport accidents" (31.2\%). The other causes are detailed in Table 3. Ungrouped by gender and age group, the same trends repeat. A year-on-year analysis of the different causes of death revealed that these two types remained constant as the most frequent every year.

By contrast, 2006, 2007, 2008 and 2011 had slight variations in the causes of mortality, where "car occupant" and "occupant of a pick-up truck or van" presented the following mortality percentages by year $(11.9 \%, 12.2 \%, 15.1 \%, 18.4 \%$, respectively) and $(7.7 \%, 5.6 \%, 10.5 \%, 10.0 \%$, respectively). "Other unspecified land transport accidents" (V89) decreased (18.9\%, 20.8\%, 8.8\%, $7.2 \%$, respectively) (Table 3 ).

In terms of the trend of types of deaths by transport accidents year-on-year from 2000 to 2011, the most stable is "pedestrian" because it has the lowest variation, with a tendency to decrease $(\mathrm{APC}=0.2 \%, \mathrm{CI}=-0.2$ to $0.5, \mathrm{p}=0.21)$. On the other hand, "occupant of pick-up truck or van" presents the greatest year-on-year increase $(\mathrm{APC}=9.4 \%, \mathrm{CI}=1.7$ to $17.7, \mathrm{p}<0.05)$ (Table 3$)$.

The trend of mortality by transport accidents between 2000 and 2012 had an APC of 0.5\% (CI $=0.0$ to $0.9, p=0.07$, what means that despite observing an increase of $0.5 \%$ every year, this increase was not statistically significant (Table 1). To be able to complement this, the mortality rate per 100,000 vehicles was calculated from 2000 to 2012, and this was 10.2. In addition, it was observed that the year with the highest rate was 2001 (17.3) and the year with the lowest rate was 2012 (6.0). In addition, the APC of -3.6 (CI $=-4.5$ to $-2.7, \mathrm{p}<0.00)$ indicates a significant year-on-year reduction in mortality rates due to vehicles.

An analysis of the trend between regions from 2000 to 2012 revealed that Antofagasta had the greatest APC $(3.4 \%$ [CI $=0.4$ to $4.8, p$ $<0.01]$ ), which indicates that the APC increased significantly every year. The Metropolitan region is the only one with a significant negative APC, $-0.6 \%$ (CI $=-0.9$ to $-0.2, p<0.05)$, which means the TAMR tended to decrease annually (Table 1).

The APC was greater in the northern zone $(2.4 \%[\mathrm{CI}=1.5$ to $3.3, p<0.01])$, and lower in the central zone, with a $1.1 \%$ variation $(\mathrm{CI}=-0.2$ to $-0.8, p=0.6$ ) (Table 2).

In the 2000-2012 period the women presented a greater APC of $0.8 \%(\mathrm{CI}=0.8$ to $1.6, p=$ 0.05) (Table 2), which indicates a slight but statistically significant increase.

Analyzing this variable by age group, the greatest observed decline of crude mortality rate was observed in the 15 to 24 age group $(\mathrm{APC}=$ - 
$0.5 \%[\mathrm{CI}=-1.0$ to $0.5, \mathrm{p}=0.10])$, which denotes a decrease in its rates over time (Table 1).

The greater risk of mortality by transport accidents in men over women was verified for 2000-2012 (RR of 4.1); this difference decreased over the years, with an APC of the RR being $-0.5 \%(\mathrm{CI}=-1.1$ to $0.2, \mathrm{p}=0.2)$ (Table 4$)$.

A greater risk of mortality by transport accidents was observed in the northern zone com- pared to the central zone ( $\mathrm{RR}$ of $1.2(\mathrm{CI}=0.9$ to $1.3)$, with a significant APC of $2.5 \%(\mathrm{CI}=1.4$ to $3.6, p<0.01)$. When contrasting the regions with the highest and lowest TAMR (O'Higgins/ Metropolitan), we found a RR of 2.2 ( $\mathrm{CI}=2.1$ to $2.4)$, with an APC of -0.1 ( $\mathrm{CI}=-0.9$ to $0.8, \mathrm{p}=$ 0.9) (Table 4).

The greater risk of mortality by transport accidents was confirmed as "pedestrians" com-

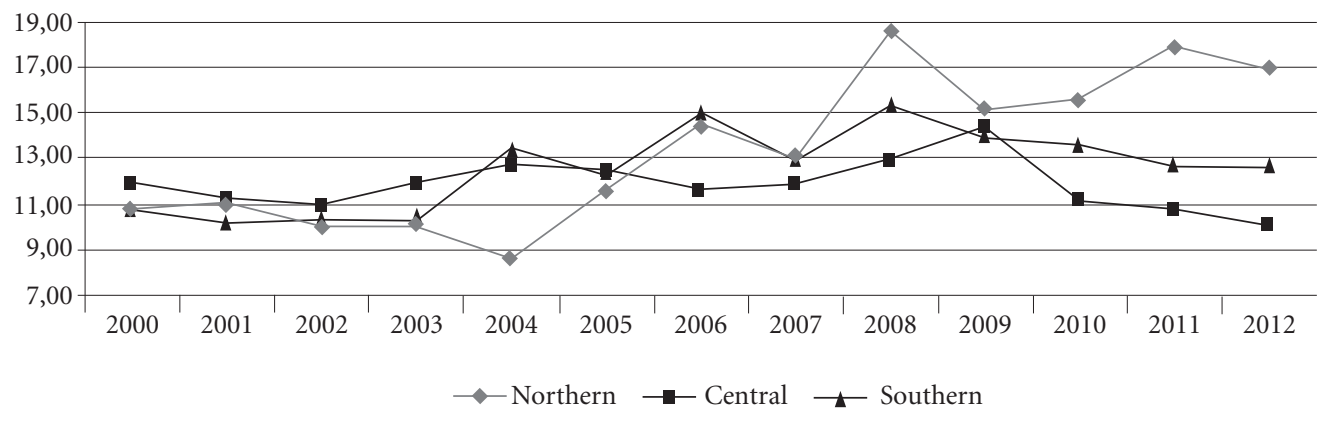

Figure 1. Transport accident mortality rate per 100,000 population by zone.

Table 3. Types of transport accident with their respective percentages and annual percentage change with 95\% CI.

\begin{tabular}{|c|c|c|c|c|c|c|}
\hline \multirow[b]{2}{*}{ Pedestrian (V01-V09) } & \multirow{2}{*}{$\begin{array}{c}\mathbf{N} \\
12080\end{array}$} & \multirow{2}{*}{$\begin{array}{c}\% \\
43.1 \%\end{array}$} & \multirow{2}{*}{$\begin{array}{c}\text { APC } \\
-0.21\end{array}$} & \multicolumn{2}{|c|}{ CI } & \multirow{2}{*}{$\frac{\mathbf{p}}{0.21}$} \\
\hline & & & & -0.52 & 0.10 & \\
\hline Pedal Cycle Rider (V10-V19) & 896 & $3.2 \%$ & 4.63 & 0.61 & 8.82 & 0.05 \\
\hline $\begin{array}{l}\text { Motorcycle rider or occupant of three-wheeled } \\
\text { motor vehicle (V20-V39) }\end{array}$ & 613 & $2.2 \%$ & 7.50 & 3.4 & 11.73 & 0.00 \\
\hline Car occupant (V40-V49) & 1625 & $5.8 \%$ & 5.86 & -1.4 & 13.62 & 0.15 \\
\hline Occupant of pick-up truck or van (V50-V59) & 889 & $3.2 \%$ & 9.44 & 1.74 & 17.71 & 0.04 \\
\hline Occupant of heavy transport vehicle (V60-V69) & 582 & $2.1 \%$ & 6.25 & 2.60 & 10.04 & 0.01 \\
\hline Bus occupant (V70-V79) & 410 & $1.5 \%$ & 4.79 & 0.8 & 8.95 & 0.04 \\
\hline Other land TA specified (V80-V88) & 662 & $2.4 \%$ & -1.33 & -3.3 & 0.67 & 0.22 \\
\hline Other land TA unspecified (V89) & 8756 & $31.2 \%$ & -4.46 & -8.30 & -0.47 & 0.05 \\
\hline Water, air, space and other TA (V90-V99) & 1528 & $5.4 \%$ & -1.86 & -3.02 & -0.68 & 0.01 \\
\hline
\end{tabular}

Table 4. Relative risk with their 95\% CI and annual percentage change of relative risks with their 95\% CI.

\begin{tabular}{lrrrrrrr}
\hline & \multicolumn{1}{c}{ RR } & \multicolumn{2}{c}{ CI } & APC & \multicolumn{2}{c}{ CI } & p \\
\hline Men/women & 4.12 & 3.90 & 4.51 & -0.45 & -1.13 & 0.24 & 0.22 \\
Northern/Central & 1.17 & 0.91 & 1.28 & 2.52 & 1.41 & 3.64 & 0.00 \\
O’Higgins/Metropolitan & 2.24 & 2.06 & 2.43 & -0.05 & -0.86 & 0.76 & 0.90 \\
Pedestrian/Bus occupant & 29.46 & 25.99 & 64.36 & -4.92 & -8.82 & -0.87 & 0.04 \\
25 to 40 / 0 to 16 years & 3.37 & 3.14 & 3.65 & -0.36 & -1.20 & 0.49 & 0.43 \\
\hline
\end{tabular}


pared to "bus occupant", (RR of 45.2 ( $\mathrm{CI}=26.0$ to 64.4)), with an APC of $-4.9(\mathrm{CI}=-8.8$ to $-0.9, \mathrm{p}$ $<0.05$ ) in the 2000-2012 period (Table 4).

A greater risk of mortality by transport accidents was verified in the 25-40 age group over the $0-16$ group ( $\mathrm{RR}$ of $3.4(\mathrm{CI}=3.1$ to 3.7$)$ ), with an APC of $-0.4(\mathrm{CI}=-1.2$ to $0.5, \mathrm{p}=0.4)$ in the study period (Table 4).

\section{Discussion}

Considering the main results of our study, we found similarities with the research conducted in Chile and the Americas on mortality by external causes, where the rates are higher in men, the south of the country and in the 25-40 age group, as well as in the trends of year-on-year increases in the rates ${ }^{11,12}$.

Perhaps there can never be enough research into transport accidents to be able to create awareness of the gravity of the increased mortality by transport accidents in Chile every year, since although the APC is never actually significant, it is always very close.

It must also be stressed that we only found negative and significant APCs in the Metropoli$\tan$ region, which is clearly where most Chileans live, but in several regions of the northern and southern zones the APCs are positive and significant, which indicates that we are not approaching the problem of transport accidents adequately and in a decentralized manner. To better understand this, we must explain that in Chile the population in 2014 was estimated at 17.8 million, with $40.6 \%$ of the inhabitants being in the Metropolitan region, and from 11.8 to $0.6 \%$ living in the other 14 regions $^{14}$.

None of this is surprising given that more than half of the countries of the Americas lack national policies that support investment in public transport and promote non-motorized transport, such as bicycles ${ }^{2}$. Therefore, it is essential to make road safety a public health priority; from this follows the need to ensure the human and financial resources to implement intersectoral actions on this issue, e.g. the proposal produced in 2011 by the PAHO as a response to the problem of the road safety $y^{4}$

The protective and risk factors associated with road safety are many, with the most common in Chile being: the reduction of speed and alcohol intake, helmet, safety belt use and a safety seat for minors ${ }^{2}$. This situation is well known, but not usually or permanently adopted by the populace. This fact (known by sector authorities) demands the need for public service campaigns, which undoubtedly would impact favorably on reducing TAMR as well as the number of those seriously injured and disabled. Since there is evidence to account for the positive impact of these measures on TAMR ${ }^{9}$, a line of research could be developed in Chile. Implementation of these measures should be undertaken with caution; first, studies to support the promotion of one measure over another must be a priority. It is also recommended that the research already conducted on this subject be critically reviewed.

In Chile there is a governing entity for road safety, the National Transit Safety Commission, which has been implementing for some time a large number of the safety measures established by international bodies (speed limits, driving with no alcohol intake, helmet use, safety belt use even in public transport vehicles, obligatory use of safety seats for children, etc. $)^{2}$. The important modifications to the traffic law include Decree 22 of $2006^{16}$ and Emilia's law of 2014, which severely punishes causing serious or critical injury or death while driving under the influence of al$\mathrm{cohol}^{17}$. However, this study does not show a reduction in TAMR in the years following the first reform. Another study shows a $7 \%$ reduction in pedestrian fatalities ${ }^{8}$.

Unfortunately, the relation between implementation of measures to improve road safety and the increase of vehicles on the roads seems out of proportion. The number of vehicles in Chile is currently estimated at more than 4 million, and it is projected that for 2025, it will range between 6.5 and 6.8 million light and medium vehicles, and the country will have 19.4 million people ${ }^{18}$.

To respond to these demands, the country needs an investment in urban transport estimated at US\$ 58.115 million to allow people to continue having access to infrastructure services in line with a country with a per capita income approaching US $\$ 20,000$ million $^{19}$. Therefore, the problems related to transport will increase in several ways more than just the mortality rates.

In spite of the effort to provide information that enables the creation of public policies to tackle the problem, the quality of the records does not help in this task. There are problems related to the under-reporting and classification, which render it difficult to ascertain the true magnitude of the problem, and therefore limit the comparability of the data in the region. For example, there is no consensus regarding the definition of death 
by transport accidents for statistical purposes (while some countries define transport-related death as that which happens at any time after the event, others limit it to only those people who die at the site of the accident $)^{2}$.

Also in Chile in relation to the types of transport accidents, we observed that $33.3 \%$ of the accidents were classified as unspecified, which makes it more difficult to be able to include this situation accurately.

Another interesting topic associated with the quality of the records are the differences and similarities between the three sources of data (PAHO, SML and CONASET) related to mortality from transport accidents in Chile.

Whereas the proportion of pedestrians who die from transport accidents is considerably higher than other types of accidents, in the future analyses excluding this group could be performed, which may provide a clearer picture of what is occurring with the other types of death.

It would be interesting to investigate in the future how psycho-social factors are associated with TAMR, e.g. those related to quality of life, to thus be able to identify which population groups require more timely intervention and how psycho-social factors are related to TAMR. It would also be interesting to be able to enquire about the relation between the number of deaths due to transport accidents and the increase in vehicles, using advanced statistical models that make it possible to combine a variety of factors, for ex- ample the analysis of inequalities using a linear regression analysis ${ }^{20}$.

It is also known that day-to-day efforts are being made to improve the records to then be able to contrast the situation in Chile with that of other countries. However, there continues to be differences among the entities that record the information, finding small differences in the number of deceased, which opens the door to investigate the reason for these incongruities.

It should be noted that the authors decided to use the concept of "transport accidents" guided by the criteria of the ICD-10 and following the WHO guidelines, without denying that in other research on this issue the concept of "road crashes" or traffic is used ${ }^{8-10,21}$.

\section{Conclusion}

This study is one of the few conducted in Chile to describe the trends in mortality from transport accidents. Finding an increase in the rates during the study period, being higher in men, the south of the country and in the 25 to 40 age group, it is worth noting that pedestrians are the most affected group. Nevertheless, changes in the trends of TAMR are predicted.

We must not forget that transport accidents are a cause of completely avoidable mortality, and it is therefore crucial to internalize this topic and implement the relevant measures to decrease mortality rates.

\section{Collaborations}

T Otzen, A Sanhueza and C Manterola conceptualized the aims and design of the study. T Otzen and A Sanhueza performed the statistical analyses. T Otzen drafted the manuscript, and A Sanhueza, C Manterola, T Melnik and M Hetz revised it critically for intellectual content. All authors read and approved the final manuscript. 


\section{References}

1. World Health Organization (WHO). Completeness and coverage of death registration data. Health statistics and information systems [on the Internet] 2014 [cited 2015 Jul 26]. Available from: http://www.who. int/healthinfo/statistics/mortcoverage/en/

2. Pan-American Health Organitation (PAHO). Data on road safety in the Region of the Americas. [on the Internet] 2013 [cited $2015 \mathrm{Jul}$ 27]. Available from: http:// www.who.int/violence_injury_prevention/road_safety_status/2013/report/factsheet_paho_es.pdf

3. World Health Organization (WHO). International Statistical Classification of Diseases and Related Health Problems 10th Revision. In. Edited by WHO [on the Internet] 2015 [cited 2015 Jul 27]. Available from: http:// apps.who.int/classifications/icd10/browse/2016/en

4. Chile. Instituto Nacional de Estadisticas [INE]. Carabineros, Informe Anual [on the Internet] 2013 [cited 2015 Jul 25]. Available from: http://www.ine.cl/canales/ menu/publicaciones/calendario_de_publicaciones/ pdf/informe_anual_carabineros_2013.pdf

5. Corporación Nacional de Seguridad y Tránsito [Conaset]. Información Estadística de Accidentes de Tránsito en Comunas, Distritos, Circunscripciones y Regiones de Chile [on the Internet] 2013 [cited 2015 Jul 26]. Available from: http://www.conaset.cl/wp-content/uploads /2014/10/Distritos_circunscripciones2013.pdf

6. Corporación Nacional de Seguridad y Tránsito [Conaset].Accidentes de Tránsito Asociados a la Presencia de Alcohol [on the Internet] 2013 [accessed 2015 Jul 29]. Available from: http://www.conaset.cl/wp-content/uploads/2015/04/alcohol_2013.pdf

7. Pan-American Health Organitation (PAHO). Informe sobre el Estado de la Seguridad Vial en la Región de Las Américas [on the Internet] 2009 [accessed 2015 Jul 28]. Available from: http://www.who.int/violence_injury_ prevention/road_safety_status/2009/gsrrs_paho.pdf

8. Nazif-Munoz JI, Quesnel-Vallee A, Van den Berg A. Explaining Chile's traffic fatality and injury reduction for 2000-2012. Traffic Inj Prev 2014; 15(Supl. 1):S56-S63.

9. Phillips RO, Ulleberg P, Vaa T. Meta-analysis of the effect of road safety campaigns on accidents. Accid Anal Prev 2011; 43(3):1204-1218.

10. Nazif-Munoz JI, Quesnel-Vallee A, Van den Berg A. Did Chile's traffic law reform push police enforcement? Understanding Chile's traffic fatalities and injuries reduction. Inj Prev 2015; 21(3):159-165.

11. Otzen T, Manterola C, Sanhueza A, Escamilla-Cejudo J. Mortalidad por suicidio en Chile: tendencias en los últimos años. Rev Med Chil 2014; 142(3):305-313.

12. Otzen T, Sanhueza A, Manterola C, Melnik T. Homicide in Chile: Trends 2000 - 2012. BMC Psychiatry 2015; 15:312.
13. Chile. Instituto Nacional de Estadisticas [INE]. Proyecciones y Estimaciones de Población. 1990-2020 [on the Internet] 2008 [cited 2015 Jul 27]. Available from: http://www.ine.cl/canales/chile_estadistico/demografia_y_vitales/proyecciones/Informes/MicrosoftWordInforReg_T.pdf

14. Chile. Instituto Nacional de Estadisticas [INE]. Actualización de Población 2002-2012 y Proyecciones 2013-2020 [on the Internet] 2014 [cited 2015 Jul 27]. Available from: http://www.ine.cl/canales/sala_prensa/ revistaseconomicas/presentaciones/pdf/proyecciones_ poblacion_2014.pdf

15. Sanhueza A, Otzen T, Manterola C, Araneda N. Statistical Approaches for Analyzing a Continuous Outcome in Experimental Studies. Int J Morphol 2014; 32(1):339350.

16. Asociación Nacional Automotriz de Chile [ANAC]. Anuario Automotriz 2014/2015 [on the Internet] 2014 [cited 2015 Jul 25]. Available from: http://www.anac.cl/ noticias/articulo/anuario-automotriz-2014-2015

17. Gobierno de Chile. Decreto 22. In., vol. 249803. Diario Oficial: Govierno de Chile. [on the Internet] 2006 [cited 2015 Jul 26]. Available from: http://www.conaset.cl/ wp-content/uploads/2014/01/dto_22_20_MAY_2006. pdf.

18. Gobierno de Chile. Ley Emilia. In., vol. 20770. Diario Oficial [on the Internet] 2014 [cited 2015 Jul 30]. Available from: http://www.conaset.cl/ley-emilia.html

19. Cámara Chilena de la Construcción [CChC]. Infraestructura Crítica para el Desarrollo, Bases para un Chile integrado [on the Internet] 2014 [cited 2015 Jul 30]. Available from: http://www.cchc.cl/uploads/archivos/archivos/Infraestructura-Critica-para-el-Desarrollo_2014-2018.pdf

20. Keppel K, Pamuk E, Lynch J, Carter-Pokras O, Kim I, Mays V, Pearcy J, Schoenbach V, Weissman JS. Methodological issues in measuring health disparities. Vital Health Stat. Edited by Statistics NCfH, vol. 2; 2005: 22.

21. Perel P, Ker K, Ivers R, Blackhall K. Road safety in lowand middle-income countries: a neglected research area. Injury Prevention 2007; 13(4):227-227.

Artigo apresentado em 07/12/2015

Aprovado em 19/07/2016

Versão final apresentada em 21/07/2016 
p. 3711

onde se lê:

Tamara Otzen ${ }^{1}$

Antonio Sanhueza ${ }^{2}$

Carlos Manterola ${ }^{1}$

Monica Hetz ${ }^{1}$

Tamara Melnik ${ }^{3}$

leia-se:

Tamara Otzen ${ }^{1}$

Antonio Sanhueza ${ }^{2}$

Carlos Manterola ${ }^{3}$

Monica Hetz ${ }^{4}$

Tamara Melnik ${ }^{5}$

onde se lê:

${ }^{1}$ Ciencias Médicas, Universidad de La Frontera. Avda. Francisco Salazar 1011. Temuco IX Región

Chile.tamara.otzen@ufrontera.ch

${ }^{2}$ Departamento de Matemática y Estadísticas, UFRO. Temuco Chile.

${ }^{3}$ Programa de Pós-Graduação em Saúde Baseada em Evidências, Universidade Federal de São Paulo. São Paulo SP Brasil.

leia-se:

${ }^{1}$ Facultad de Ciencias de la Salud, Universidad de Tarapacá. Calle 18 de Septiembre 2222. 1010069 Arica Tarapaca Chile.

tamara.otzen@ufrontera.ch

${ }^{2}$ Pan American Health Organization.

Washington USA.

${ }^{3}$ Universidad de La Frontera. Temuco Chile.

${ }^{4}$ Universidad Católica de Temuco. Temuco

Chile.

${ }^{5}$ Programa de Pós-Graduação em Saúde Baseada em Evidências, Universidade Federal de São Paulo. São Paulo SP Brasil. 